\title{
Individuals Diagnosed with Binge-Eating Disorder Have DNA Hypomethylated Sites in Genes of the Metabolic System: A Pilot Study
}

\author{
Mariana Lizbeth Rodríguez-López ${ }^{1}$, José Jaime Martínez-Magaña ${ }^{1}$ D, David Ruiz-Ramos ${ }^{2}$, Ana Rosa García ${ }^{3}$, \\ Laura Gonzalez $^{4}$, Carlos Alfonso Tovilla-Zarate ${ }^{5}$ D , Emmanuel Sarmiento ${ }^{3}$, Isela Esther Juárez-Rojop ${ }^{2}$, \\ Humberto Nicolini ${ }^{1, *(D)}$, Thelma Beatriz Gonzalez-Castro ${ }^{6}{ }^{\mathbb{D}}$ and Alma Delia Genis-Mendoza ${ }^{1, *}$
}

check for updates

Citation: Rodríguez-López, M.L.; Martínez-Magaña, J.J.; Ruiz-Ramos, D.; García, A.R.; Gonzalez, L.; Tovilla-Zarate, C.A.; Sarmiento, E.; Juárez-Rojop, I.E.; Nicolini, H.; Gonzalez-Castro, T.B.; et al. Individuals Diagnosed with Binge-Eating Disorder Have DNA Hypomethylated Sites in Genes of the Metabolic System: A Pilot Study. Nutrients 2021, 13, 1413. https:// doi.org/10.3390/nu13051413

Academic Editor: Dina Bellizzi

Received: 3 March 2021

Accepted: 16 April 2021

Published: 22 April 2021

Publisher's Note: MDPI stays neutral with regard to jurisdictional claims in published maps and institutional affiliations.

Copyright: (C) 2021 by the authors. Licensee MDPI, Basel, Switzerland. This article is an open access article distributed under the terms and conditions of the Creative Commons Attribution (CC BY) license (https:/ / creativecommons.org/licenses/by/ $4.0 /)$.
1 Genomics of Psychiatric and Neurodegenerative Diseases Laboratory, National Institute of Genomic Medicine (INMEGEN), Mexico City 01090, Mexico; marianalrl_1802@hotmail.com (M.L.R.-L.); jimy.10.06@gmail.com (J.J.M.-M.)

2 Biomedical Postgraduate Program, Academic Division of Health Sciences, Juárez Autonomous University of Tabasco, Villahermosa 86000, Mexico; daruiz_914@hotmail.com (D.R.-R.); iselajuarezrojop@hotmail.com (I.E.J.-R.)

3 Children's Psychiatric Hospital “Dr. Juan N. Navarro”, Mexico City 01090, Mexico; anarosagarciab@gmail.com (A.R.G.); emmanuelsarmientoh@hotmail.com (E.S.)

4 National Institute of Psychiatry “Dr. Ramón de la Fuente Muñiz”, Mexico City 01090, Mexico; macias@imp.edu.mx

5 Genomics Laboratory, Comalcalco Multidisciplinary Academic Division, Juárez Autonomous University of Tabasco, Villahermosa 86000, Mexico; alfonso_tovillaz@yahoo.com.mx

6 Genomics Laboratory, Academic Division Jalpa de Mendez, Juárez Autonomous University of Tabasco, Jalpa de Mendez 86200, Mexico; thelma.glez.castro@gmail.com

* Correspondence: hnicolini@inmegen.gob.mx (H.N.); adgenis@inmegen.gob.mx (A.D.G.-M.); Tel.: +52-(53)-501900 (ext. 1196/1197) (H.N. \& A.D.G.-M.)

Abstract: Binge-eating disorder, recently accepted as a diagnostic category, is differentiated from bulimia nervosa in that the former shows the presence of binge-eating episodes and the absence of compensatory behavior. Epigenetics is a conjunct of mechanisms (like DNA methylation) that regulate gene expression, which are dependent on environmental changes. Analysis of DNA methylation in eating disorders shows that it is reduced. The present study aimed to analyze the genome-wide DNA methylation differences between individuals diagnosed with BED and BN. A total of 46 individuals were analyzed using the Infinium Methylation EPIC array. We found 11 differentially methylated sites between BED- and BN-diagnosed individuals, with genome-wide significance. Most of the associations were found in genes related to metabolic processes (ST3GAL4, PRKAG2, and FRK), which are hypomethylated genes in BED. Cg04781532, located in the body of the PRKAG2 gene (protein kinase AMP-activated non-catalytic subunit gamma 2), was hypomethylated in individuals with BED. Agonists of PRKAG2, which is the subunit of AMPK (AMP-activated protein kinase), are proposed to treat obesity, BED, and BN. The present study contributes important insights into the effect that BED could have on PRKAG2 activation.

Keywords: eating disorders; binge-eating disorder; bulimia nervosa; DNA methylation; AMPK

\section{Introduction}

Bulimia nervosa (BN) and binge-eating disorder (BED) are classified as eating disorders (EDs), which are mental disorders characterized by an alteration in eating behaviors $[1,2]$. These disorders are present worldwide, with a prevalence ranging from $1.0 \%$ to $2.0 \%$ [3-6]. BN and BED are highly related but differ in terms of restrictive behavior. Individuals diagnosed with $\mathrm{BN}$ have a fear of gaining weight in combination with recurrent binge eating episodes (i.e., consumption of large amounts of food in short periods of time, with a loss of control), followed by compensatory behaviors [7,8]. Meanwhile, individuals 
diagnosed with BED have binge eating episodes, but these episodes are not followed by compensatory behaviors $[1,8]$. BED has recently been recognized as a separate disorder, while it was previously included in eating disorders not otherwise specified. Studies of this disorder are still missing $[9,10]$. Despite the differences between BN and BED, some authors have proposed that BED could be a severe eating disorder. This increased severity is related to a higher presence of psychiatric metabolic comorbidities [10-17], the ability to differentiate between these disorders is essential for health providers, as it allows them to provide the correct treatment. Later, eating disorders were considered adult-onset disorders, but recent studies have reported that the early-onset of these disorders is correlated with a higher severity [18-21].

$\mathrm{BN}$ and BED are considered complex traits, since their etiology is the effect of the accumulation of different biological, social, and environmental factors [22,23]. In this sense, epigenetics is the processes that influence the expression of genes, without changing the gene structure [22,24]. Epigenetics has been proposed as the link between environmental changes and gene expression. It is the process by which an organism changes its phenotype in response to the environment [25]. The environment could be as simple as the cell microenvironment or as complex as metabolic changes, drug use, or stressful stimuli [26]. The most studied epigenetic change in humans is the dysregulation of the DNA methylation profile $[22,27,28]$. DNA methylation is found in the $5^{\prime}$ position of the cytosine, and it is necessary for the repression of gene expression [29-33]. However, the study of methylation in eating disorders is still lacking. The main studies have focused on candidate regions, with few studies on genome-wide DNA methylation scanning [24]. DNA methylation occurs in the $5^{\prime}$ position of cytosine, and guanine is in the next position. This cytosine is known as the CpG site, and if it is methylated, it is also called a methylated site [23]. To date and as far as we know, there has not been any epigenetic study on individuals diagnosed with BED [23]. The hypomethylation of the promoter of the atrial natriuretic peptide and dopamine transporter in individuals diagnosed with BN has been reported [23,34,35]. Additionally, another study of ED-diagnosed individuals demonstrated hypermethylation on the oxytocin receptor, which was negatively correlated with body mass index (BMI) [36], pointing to a relationship between the effect of ED on BMI and epigenetic changes. Nevertheless, the epigenetics of ED is still an emerging field.

Several studies are exploring epigenetic factors, but no studies have focused on the differences between disorders. As mentioned, BN and BED are differentiated in terms of compensatory behaviors. Nevertheless, it is not known whether the presence of these compensatory behaviors is enough to promote epigenetic changes. In this sense, the present study aims to compare the genome-wide DNA methylation profiles of individuals diagnosed with BN and BED. We hypothesized that the lack of compensatory behaviors could promote epigenetic changes between BN and BED. As far as we know, this is the first study to explore DNA methylation data in Mexican adolescents diagnosed with EDs.

\section{Materials and Methods}

\subsection{Study Design}

This was a cross-sectional study, with a sample-based design.

\subsection{Sample Population}

In this analysis, we included a total of 46 individuals, with 25 diagnosed with $\mathrm{BN}$ and 21 with BED. The individuals were recruited from the area of external consultation of the Hospital Psiquiátrico Infantil Juan N Navarro. The inclusion criteria included children or adolescent (age between 8-17 years), enrolled between 2016-2018, diagnosed with BED or $\mathrm{BN}$ only, non-tobacco users, and neither medical nor illegal drugs users. All evaluations were performed by psychiatrists specializing in eating disorders. The recruitment was performed by means of psychiatric treatment. The psychiatrist invited the children or adolescents to participate by speaking with their parents, with a previous explanation that not accepting to participate would not impact their treatment in any way. Besides, 
no monetary compensation was delivered. Once the aims of the study were exposed, the children/adolescents signed an informed assent, and their parents signed an informed consent. The evaluation of eating patterns was performed using the Spanish version of the Questionnaire on Eating and Weight Patterns-5 (QEWPR-5) and the Eating Attitude Test-26 [37,38]. The present work was approved by the research and ethics committee of the Hospital Psiquiátrico Infantil Juan N Navarro (Number = II3/01/0913) and the Instituto Nacional de Medicina Genómica (Number = 06/2018/I).

\subsection{Anthropometric and Clinical Characteristics}

The age, gender, scholarship, and parents/grandparents' country of birth of the participants were collected using a structured questionnaire of all the individuals. The anthropometric measurements collected included the weight and height, as previously reported [39]. The body mass index (BMI) was determined according to the obesity task force criteria. One of the limitations of the use of BMI on children and adolescents is that this parameter could be influenced by the development of the child. In order to conduct a comparison of the participants' BMI, we transformed this value into z-score (z-BMI) values, according to previous reports $[40,41]$. Screening of binge-eating behavior was performed with the QEWPR-5 and EAT-26, and the diagnostic confirmation was performed by the children's specialized psychiatrist. QEWPR-5 is a structured questionnaire that allows for the screening of binge-eating disorders based on the DSM-5 criteria. Meanwhile, the EAT-26 is a structured questionnaire that allows for the diagnosis of bulimia nervosa.

The mean age of the participants was 13.91 (Table 1). Of the total 45 adolescents, 12 were males, and 34 were females. Non-individuals diagnosed with BED had compensatory behavior. The mean z-score value for body mass index (BMI) in the total sample was 1.25. Thus, based on the 2007 WHO growth chart reference for school-age children and adolescents, 12 of the participants were overweight, and 19 were obese [40]. The individuals with BED had a higher BMI, compared to the BN individuals $(t=-4.02$, $p$-value $=2.24 \times 10^{-4}$ ), as evaluated by the Student's $t$-test. As expected, none of the individuals diagnosed with BED had compensatory behavior.

Table 1. Sample description.

\begin{tabular}{cccc}
\hline & BN $(\boldsymbol{n = 2 5 )}$ & BED $(\boldsymbol{n}=\mathbf{2 1})$ & Total $(\boldsymbol{n}=\mathbf{4 6})$ \\
\hline Gender & & & \\
Female $(n, \%)$ & $22(88.00)$ & $12(57.14)$ & $34(73.91)$ \\
Male $(n, \%)$ & $3(12.00)$ & $9(42.86)$ & $12(26.09)$ \\
Age (s.d) & $13.76(1.56)$ & $14.10(1.51)$ & $13.91(1.53)$ \\
Body Mass Index & & & \\
BMI z-score $(\mathrm{s.d})$ & $0.87(0.74)$ & $1.69(0.65)$ & $1.25(0.81)$ \\
Normal weight $(n, \%)$ & $14(56.00)$ & $1(4.76)$ & $15(32.61)$ \\
Overweight $(n, \%)$ & $5(20.00)$ & $7(33.33)$ & $19(41.30)$ \\
Obese $(n, \%)$ & $6(24.00)$ & $13(61.90)$ & \\
Eating behavior & & & $25(47.83)$ \\
Compensatory $(n, \%)$ & $25(100.0)$ & $0(0.00)$ & $38(82.61)$ \\
Binge eating $(n, \%)$ & $17(68.00)$ & $21(100.00)$ &
\end{tabular}

Notes. BN = Bulimia Nervosa, BED = binge-eating disorder, s.d = standard deviation.

\subsection{DNA Extraction and Microarray DNA Methylation}

Once the diagnostic was confirmed, the informed assent/consent was signed, and only if the adolescents accepted to donate the sample, a tube with blood and EDTA (anticlotting agent) was collected by venipuncture. Whole blood samples were collected, and the DNA was extracted using the Gentra Puregene Blood Kit (Qiagen, Germantown, MD, USA), according to the manufacturer's protocol. The DNA was converted using bisulfite with the Zymo research kit (Zymo, Irvine, CA, USA). The bisulfite-converted DNA was hybridized to the Illumina Infinium Methylation EPIC microarray beadchip (Illumina, San Diego, CA, USA), following the manufacturer's microarray protocol. The 
fluorescence intensity was scanned using iScan, and it was transformed into idat files using the GenomeStudio software (Illumina, USA). Quality control was also applied using the ChAMP package [42], according to previously published algorithms. Briefly, we removed the probes using (i) $p$-value detection (higher than 0.01); (ii) less than 3 beads in less than $5 \%$ of the samples; (iii) all non-CpGs sites; (iv) SNP-associated probes; (v) sexual chromosomeassociated probes; and (vi) multi-hit probes. Samples with a ratio higher than 0.1 were also removed. Normalization was performed using the beta-mixture quantile normalization method, batch effect removal (slide, array, gender, and age), and adjustment by blood cell proportions were performed, following the algorithm implemented in ChAMP [43].

\subsection{Differential Methylated Sites Analysis}

For these analyses, we used the beta values from the quality control file of the ChAMP package, and a comparison of the groups was performed using the linear models of the limma package [44]. We compared BN with BED and also analyzed BMI (with the z-scores of BMI as the numerical variable). We considered a value statistically significant if the $p$-values were lower than $5 \times 10^{-8}$ (genome-wide significance). We annotated the sites to their gene location (1st Exon, 3'UTR, 5'UTR, Body, Exon Bound, TSS1500, and TSS200) based on the EPIC array manifest. Based on the sample size, we performed a power analysis using the pwrEWAS package [45]. Expecting a difference of betas (delta of Beta) of 0.03 , we reached a statistical power of $41.0 \%$.

\section{Results}

Differentially Methylated Sites in BN and BED

In the comparison of bulimia nervosa and binge-eating disorder, we found 11 differentially methylated sites at a genome-wide level $\left(p\right.$-value $\left.<5 \times 10^{-8}\right)$ (Figure 1 ).

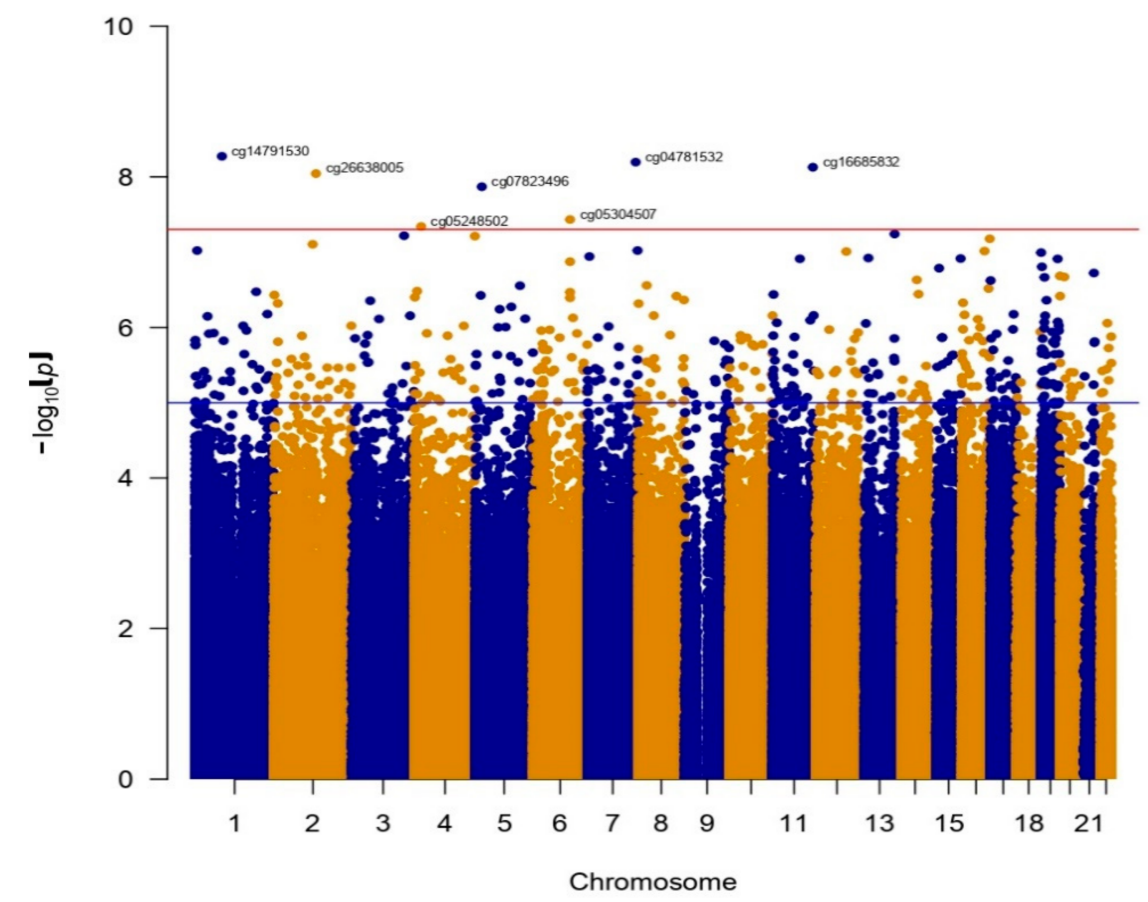

Figure 1. Manhattan plot of the comparison of BED and BN.

Of the 11 sites, 4 were intergenic, and 7 were located in gene-coding regions (CTBS, SLITRK3, PACRGL, FRK, PRKAG2, ST3GAL4, and BANP) (Table 2). In the gene position, 2 sites were in transcription starting sites, 2 sites were in the gene body, 1 was in the first exon, and 1 was in the untranslated region. 
Table 2. Differentially methylated sites in bulimia nervosa and binge-eating disorder.

\begin{tabular}{|c|c|c|c|c|c|c|c|c|}
\hline Position $^{1}$ & CpG Site & $\operatorname{LogFC}^{2}$ & $p$-Value & BED Avg & BN Avg & Gene & Gene Loc ${ }^{3}$ & $\mathrm{CGI}^{4}$ \\
\hline $1: 85040857$ & cg14791530 & -0.0499 & $5.3305 \times 10^{-9}$ & 0.8150 & 0.8550 & CTBS & TSS1500 & Shore \\
\hline 2:131090049 & cg26638005 & -0.0509 & $9.0552 \times 10^{-9}$ & 0.3135 & 0.3644 & & IGR & OpenSea \\
\hline 3:164907027 & cg00059161 & 0.0216 & $6.0427 \times 10^{-8}$ & 0.7929 & 0.7713 & SLITRK3 & Body & OpenSea \\
\hline $4: 20702180$ & cg05248502 & 0.0211 & $4.5662 \times 10^{-8}$ & 0.0737 & 0.0526 & PACRGL & 1st Exon & Island \\
\hline $4: 189258348$ & cg22740817 & -0.0138 & $6.1212 \times 10^{-8}$ & 0.9427 & 0.9565 & & IGR $^{5}$ & OpenSea \\
\hline 5:20305935 & cg07823496 & -0.0386 & $1.3534 \times 10^{-8}$ & 0.9039 & 0.9424 & & IGR & Island \\
\hline $6: 116381966$ & cg05304507 & -0.0765 & $3.6910 \times 10^{-8}$ & 0.7500 & 0.8265 & FRK & TSS200 & OpenSea \\
\hline 7:151565722 & $\operatorname{cg} 04781532$ & -0.0190 & $6.3694 \times 10^{-9}$ & 0.9376 & 0.9566 & PRKAG2 & Body & OpenSea \\
\hline $11: 126284163$ & cg16685832 & -0.0282 & $7.4533 \times 10^{-9}$ & 0.8750 & 0.9032 & ST3GAL4 & $3^{\prime}$-UTR & Shelf \\
\hline 13:114318347 & cg21211187 & -0.0115 & $5.7405 \times 10^{-8}$ & 0.9501 & 0.9616 & & IGR & OpenSea \\
\hline 16:88110197 & cg10838260 & -0.0245 & $6.6465 \times 10^{-8}$ & 0.8966 & 0.9211 & $B A N P$ & Body & Island \\
\hline
\end{tabular}

Notes: ${ }^{1}$ Human genome position of the CpG site (GRCh37/hg19). ${ }^{2}$ LogFC $=$ logarithm of fold change. ${ }^{3}$ Gene Loc $=$ location of the CpG site relative to the coding gene. ${ }^{4} \mathrm{CGI}=\mathrm{CpG}$ island. ${ }^{5} \mathrm{IGR}=$ Intergenic region.

Only three sites were CpG islands, 6 were in Open Sea, 1 was in the shelf, and 1 was on the shore. Of the $11 \mathrm{CpG}$ sites, 9 were hypomethylated in individuals diagnosed with BED. The cg00059161 and cg05248502 were hypermethylated in BED-diagnosed individuals. The higher difference between the groups was found in the cg05304507 associated to the promoter of $F R K$. Additionally, cg05304507 was hypomethylated in individuals diagnosed with BED. In the analysis of differentially methylated sites with BMI, we did not find any CpG site that reached a genome-wide association $\left(p\right.$-value $\left.<5 \times 10^{-8}\right)$.

\section{Discussion}

Binge-eating disorder (BED) and bulimia nervosa (BN) are differentiated compensatory behaviors in individuals diagnosed with BED. During a binge eating episode, individuals tend to eat fat-rich foods and, as a consequence, have a higher caloric intake [46-49]. The higher caloric intake has a direct impact in promoting a higher BMI in individuals diagnosed with BED (also seen in this study), and as a consequence, this promotes a higher metabolic disturbance (like adiposity increase) [50-52]. Some studies using genetic scoring and Mendelian randomization studies have proposed that epigenetic changes are a consequence of this metabolic disturbance [53-55]. One gene that could be influenced by this metabolic disturbance is PRKAG2. PRKAG2 encodes the $\gamma 2$-subunit isoform of the AMP-activated protein kinase (AMPK), which is a cellular energy sensor and modulates energy homeostasis [56-58]. AMPK is a heterotrimeric serine-threonine kinase that senses cellular energetics, and the activated form triggers the catabolic process and represses anabolic biosynthesis $[59,60]$. Beyond the metabolic effect, AMPK is essential for the orexigenic effect of ghrelin [61-63]. Constitutively, the expression of an active form of AMPK, by recombinant adenoviral expression, acutely increases mice food intake and body weight, suggesting the central role of AMPK in the regulation of eating behavior $[64,65]$. Furthermore, the chronic expression of PRKAG2 promotes hyperphagia and obesity [66]. In homology, we can see that individuals diagnosed with BED had hypomethylated PRKAG2, suggesting a higher expression of the gene, compared to individuals diagnosed with BN. Nevertheless, the effect of the activation of the former depends on the neuron population [67]. The present result could have a high relevance in terms of the design and use of drugs to activate the AMPK pathway used in the treatment of BED, BN, obesity, and diabetes mellitus type II [68-71].

Another gene with hypomethylated $\mathrm{CpG}$ sites in individuals diagnosed with BED, and not in those diagnosed with BN, is ST3GAL4. ST3GAL4, ST3 beta-galactoside alpha2,3-sialyltransferase 4 , is one of the six enzymes that catalyzes Sia-2,3Gal linkages at the ends of glycoproteins. A deficiency of this enzyme in mice is concomitant with depressionand anxiety-like behavior [72,73]. Such behaviors could be important in the modulation of the mood of individuals diagnosed with BED, principally because depression and anxiety are the more common comorbidities found in individuals with this condition. 
The gene that showed the most differences was FRK (fyn-related kinase). FRK is a $59 \mathrm{KDa}$ tyrosine kinase protein that belongs to the Src family $[74,75]$. The former has recently been reported to play a crucial role in diabetes induction and the increase of proinflammatory signals [76-78]. The activation of $F R K$ induces cytotoxic signals to the beta pancreatic cells in response to several cytokines or beta cell toxins (like streptozotocin) $[79,80]$, thus promoting the induction of diabetes. Our results showed a hypomethylation of FRK in BED, compared to BN, suggesting an overexpression of the gene, which could lead to a higher induction of cytotoxic signals. This change in methylation could point to a higher risk of metabolic dysfunction in individuals diagnosed with BED, compared to those diagnosed with BN.

Even when we found interesting associations in the effect that BED could have on epigenomes, compared to BN, we noticed some limitations of our work. The main one is the sample size, which imitates the statistical power of our associations. Another limitation is associated with the lack of biochemical and food intake data, principally during the binge eating episodes. These data could help us to better characterize the epigenetic changes due to environmental sources. Another point to mention is that we did not find any associations with BMI, which may be because this construct cannot be perfectly measured in individuals diagnosed with ED. This limitation could pose some issues, as individuals diagnosed with ED are generally more worried about other weight constructs than they are about BMI [81]. Nevertheless, further analysis of the phenotype and a larger sample are required to replicate our findings.

\section{Conclusions}

Individuals diagnosed with BED showed hypomethylation in genes of the metabolic system, and those diagnosed with BN did not. The present result could be important in connection with the use of agonists or activators of AMPK in the treatment of BED, BN, or obesity.

Author Contributions: Conceptualization, J.J.M.-M., H.N., and A.D.G.-M.; Methodology, A.D.G.-M.; Software, J.J.M.-M. and M.L.R.-L.; Validation, A.D.G.-M., D.R.-R., A.R.G., L.G., C.A.T.-Z., E.S., and I.E.J.-R.; Formal analysis, J.J.M.-M. and M.L.R.-L.; Investigation, T.B.G.-C., J.J.M.-M.; Resources, J.J.M.-M.; Data curation, M.L.R.-L.; Writing-Original draft preparation, J.J.M.-M., D.R.-R., A.R.G., C.A.T.-Z., I.E.J.-R., and M.L.R.-L.; Writing—review and editing, H.N. and A.D.G.-M.; Visualization, D.R.-R.; Supervision, H.N.; Project administration, A.D.G.-M.; Funding acquisition, H.N. All authors have read and agreed to the published version of the manuscript.

Funding: This research was funded by Fundación Gonzalo Río Arronte, grant number S591 and Instituto Nacional de Medicina Genómica (grant no. 06/2018/I).

Institutional Review Board Statement: The study was conducted according to the guidelines of the Declaration of Helsinki and was approved by the Ethics Committees of the Instituto Nacional de Medicina Genómica (protocol code: 06/2018/I; and date: 06/5018) and Hospital Psiquiátrico Infantil Juan N Navarro (protocol code: II3/01/0913; and date: 10/2017).

Informed Consent Statement: Informed consent and assent were obtained from all subjects involved in the study.

Data Availability Statement: The data presented in this study are available in the Supplementary material. Additional data are available on request from the corresponding author, which were omitted due to privacy and ethical issues.

Acknowledgments: We want to acknowledge the Unidad de Microarreglos del Instituto Nacional de Medicina Genómica for their technical support.

Conflicts of Interest: The authors declare no conflict of interest. 


\section{References}

1. Kornstein, S.G.; Kunovac, J.L.; Herman, B.K.; Culpepper, L. Recognizing Binge-Eating Disorder in the Clinical Setting: A Review of the Literature. Prim. Care Companion CNS Disord. 2016, 18. [CrossRef] [PubMed]

2. Mathes, W.F.; Brownley, K.A.; Mo, X.; Bulik, C.M. The biology of binge eating. Appetite 2009, 52, 545-553. [CrossRef] [PubMed]

3. Hudson, J.I.; Hiripi, E.; Pope, H.G.J.; Kessler, R.C. The prevalence and correlates of eating disorders in the National Comorbidity Survey Replication. Biol. Psychiatry 2007, 61, 348-358. [CrossRef] [PubMed]

4. Kessler, R.C.; Berglund, P.A.; Chiu, W.T.; Deitz, A.C.; Hudson, J.I.; Shahly, V.; Aguilar-Gaxiola, S.; Alonso, J.; Angermeyer, M.C.; Benjet, C.; et al. The prevalence and correlates of binge eating disorder in the World Health Organization World Mental Health Surveys. Biol. Psychiatry 2013, 73, 904-914. [CrossRef]

5. Mitchison, D.; Hay, P.J. The epidemiology of eating disorders: Genetic, environmental, and societal factors. Clin. Epidemiol. 2014, 6, 89-97. [CrossRef]

6. Ruiz-Lázaro, P.M.; Comet, M.P.; Calvo, A.I.; Zapata, M.; Cebollada, M.; Trébol, L.; Lobo, A. Prevalence of eating disorders in early adolescent students. Actas Esp. Psiquiatr. 2010, 38, 204-211.

7. Fairburn, C.G.; Harrison, P.J. Eating Disorders. Lancet 2003, 361, 407-416. [CrossRef]

8. Mehler, P.S.; Rylander, M. Bulimia Nervosa-Medical complications. J. Eat. Disord. 2015, 3, 12. [CrossRef]

9. Amianto, F.; Ottone, L.; Abbate Daga, G.; Fassino, S. Binge-eating disorder diagnosis and treatment: A recap in front of DSM-5. BMC Psychiatry 2015, 15, 70. [CrossRef]

10. Jordan, J.; McIntosh, V.V.W.; Carter, J.D.; Rowe, S.; Taylor, K.; Frampton, C.M.A.; McKenzie, J.M.; Latner, J.; Joyce, P.R. Bulimia nervosa-nonpurging subtype: Closer to the bulimia nervosa-purging subtype or to binge eating disorder? Int. J. Eat. Disord. 2014, 47, 231-238. [CrossRef]

11. Grilo, C.M.; White, M.A.; Gueorguieva, R.; Wilson, G.T.; Masheb, R.M. Predictive significance of the overvaluation of shape/weight in obese patients with binge eating disorder: Findings from a randomized controlled trial with 12-month follow-up. Psychol. Med. 2013, 43, 1335-1344. [CrossRef]

12. Fassino, S.; Leombruni, P.; Pierò, A.; Abbate-Daga, G.; Giacomo Rovera, G. Mood, eating attitudes, and anger in obese women with and without Binge Eating Disorder. J. Psychosom. Res. 2003, 54, 559-566. [CrossRef]

13. Robinson, A.H.; Safer, D.L. Moderators of dialectical behavior therapy for binge eating disorder: Results from a randomized controlled trial. Int. J. Eat. Disord. 2012, 45, 597-602. [CrossRef]

14. Peterson, C.B.; Swanson, S.A.; Crow, S.J.; Mitchell, J.E.; Agras, W.S.; Halmi, K.A.; Crosby, R.D.; Wonderlich, S.A.; Berg, K.C. Longitudinal stability of binge-eating type in eating disorders. Int. J. Eat. Disord. 2012, 45, 664-669. [CrossRef]

15. Castellini, G.; Lo Sauro, C.; Mannucci, E.; Ravaldi, C.; Rotella, C.M.; Faravelli, C.; Ricca, V. Diagnostic crossover and outcome predictors in eating disorders according to DSM-IV and DSM-V proposed criteria: A 6-year follow-up study. Psychosom. Med. 2011, 73, 270-279. [CrossRef]

16. Striegel-Moore, R.H.; Cachelin, F.M.; Dohm, F.-A.; Pike, K.M.; Wilfley, D.E.; Fairburn, C.G. Comparison of binge eating disorder and bulimia nervosa in a community sample. Int. J. Eat. Disord. 2001, 29, 157-165. [CrossRef]

17. Ruiz-Ramos, D.; Martínez-Magaña, J.J.; García, A.R.; Juarez-Rojop, I.E.; González-Castro, T.B.; Tovilla-Zárate, C.A.; Sarmiento, E.; López-Narvaez, M.L.; Sanchez, N.; Genis-Mendoza, A.D. Psychiatric Comorbidity in Mexican Adolescents with a Diagnosis of Eating Disorders Its Relationship with the Body Mass Index. Int. J. Environ. Res. Public Health 2021, 18. [CrossRef]

18. Rikani, A.A.; Choudhry, Z.; Choudhry, A.M.; Ikram, H.; Asghar, M.W.; Kajal, D.; Waheed, A.; Mobassarah, N.J. A critique of the literature on etiology of eating disorders. Ann. Neurosci. 2013, 20, 157-161. [CrossRef]

19. Fairburn, C.G.; Cooper, Z.; Bohn, K.; O'Connor, M.E.; Doll, H.A.; Palmer, R.L. The severity and status of eating disorder NOS: Implications for DSM-V. Behav. Res. Ther. 2007, 45, 1705-1715. [CrossRef]

20. Sim, L.A.; McAlpine, D.E.; Grothe, K.B.; Himes, S.M.; Cockerill, R.G.; Clark, M.M. Identification and treatment of eating disorders in the primary care setting. Mayo Clin. Proc. 2010, 85, 746-751. [CrossRef]

21. Halmi, K.A. Anorexia nervosa: An increasing problem in children and adolescents. Dialogues Clin. Neurosci. 2009, 11, 100-103. [CrossRef]

22. Tammen, S.A.; Friso, S.; Choi, S.W. Epigenetics: The link between nature and nurture. Mol. Asp. Med. 2013, 34, 753-764. [CrossRef]

23. Bulik, C.M.; Yilmaz, Z.; Hardaway, J.A. Genetics and epigenetics of eating disorders. Adv. Genom. Genet. 2015, 5, 131-150. [CrossRef]

24. Hübel, C.; Marzi, S.J.; Breen, G.; Bulik, C.M. Epigenetics in eating disorders: A systematic review. Mol. Psychiatry 2019, 24, 901-915. [CrossRef]

25. Turner, B.M. Epigenetic responses to environmental change and their evolutionary implications. Philos. Trans. R. Soc. Lond. Ser. B Biol. Sci. 2009, 364, 3403-3418. [CrossRef]

26. Alegría-Torres, J.A.; Baccarelli, A.; Bollati, V. Epigenetics and lifestyle. Epigenomics 2011, 3, 267-277. [CrossRef]

27. Weinhold, B. Epigenetics: The science of change. Environ. Health Perspect. 2006, 114, A160-A167. [CrossRef]

28. Moosavi, A.; Motevalizadeh Ardekani, A. Role of Epigenetics in Biology and Human Diseases. Iran. Biomed. J. 2016, 20, 246-258. [CrossRef]

29. Barbarino, J.M.; Whirl-Carrillo, M.; Altman, R.B.; Klein, T.E. PharmGKB: A worldwide resource for pharmacogenomic information. Wiley Interdiscip. Rev. Syst. Biol. Med. 2018, 10, e1417. [CrossRef]

30. Razin, A.; Cedar, H. DNA methylation and gene expression. Microbiol. Rev. 1991, 55, 451-458. [CrossRef] 
31. Zhong, H.; Kim, S.; Zhi, D.; Cui, X. Predicting gene expression using DNA methylation in three human populations. PeerJ 2019, 7, e6757. [CrossRef] [PubMed]

32. Blagosklonny, M.V. Disease or not, aging is easily treatable. Aging 2018, 10, 3067-3078. [CrossRef] [PubMed]

33. Lim, Y.C.; Li, J.; Ni, Y.; Liang, Q.; Zhang, J.; Yeo, G.S.H.; Lyu, J.; Jin, S.; Ding, C. A complex association between DNA methylation and gene expression in human placenta at first and third trimesters. PLoS ONE 2017, 12, e0181155. [CrossRef] [PubMed]

34. Zerwas, S.; Bulik, C.M. Genetics and Epigenetics of Eating Disorders. Psychiatr. Ann. 2011, 41, 532-538. [CrossRef]

35. Steiger, H.; Booij, L. Eating Disorders, Heredity and Environmental Activation: Getting Epigenetic Concepts into Practice. J. Clin. Med. 2020, 9, 1332. [CrossRef]

36. Kim, Y.-R.; Kim, J.-H.; Kim, M.J.; Treasure, J. Differential methylation of the oxytocin receptor gene in patients with anorexia nervosa: A pilot study. PLoS ONE 2014, 9, e88673. [CrossRef]

37. Yanovski, S.Z.; Marcus, M.D.; Wadden, T.A.; Walsh, B.T. The Questionnaire on Eating and Weight Patterns-5: An updated screening instrument for binge eating disorder. Int. J. Eat. Disord. 2015, 48, 259-261. [CrossRef]

38. Rivas, T.; Bersabé, R.; Jiménez, M.; Berrocal, C. The eating attitudes test (EAT-26): Reliability and validity in spanish female samples. Span. J. Psychol. 2010, 13, 1044-1056. [CrossRef]

39. Tovilla-Zárate, C.; Juárez-Rojop, I.; Peralta Jimenez, Y.; Jiménez, M.A.; Vázquez, S.; Bermúdez-Ocaña, D.; Ramón-Frías, T.; Genis Mendoza, A.D.; García, S.P.; Narváez, L.L. Prevalence of anxiety and depression among outpatients with type 2 diabetes in the Mexican population. PLoS ONE 2012, 7, e36887. [CrossRef]

40. Hernández-Cordero, S.; Cuevas-Nasu, L.; Morán-Ruán, M.C.; Méndez-Gómez Humarán, I.; Ávila-Arcos, M.A.; Rivera-Dommarco, J.A. Overweight and obesity in Mexican children and adolescents during the last 25 years. Nutr. Diabetes 2017, 7. [CrossRef]

41. Shamah-Levy, T.; Campos-Nonato, I.; Cuevas-Nasu, L.; Hernández-Barrera, L.; Morales-Ruán, M.d.C.; Rivera-Dommarco, J.; Barquera, S. Overweight and obesity in Mexican vulnerable population. Results of Ensanut 100k. Salud Publica Mex. 2019, 61, 852-865. [CrossRef]

42. Tian, Y.; Morris, T.J.; Webster, A.P.; Yang, Z.; Beck, S.; Feber, A.; Teschendorff, A.E. ChAMP: Updated methylation analysis pipeline for Illumina BeadChips. Bioinformatics 2017, 33, 3982-3984. [CrossRef]

43. Houseman, E.A.; Accomando, W.P.; Koestler, D.C.; Christensen, B.C.; Marsit, C.J.; Nelson, H.H.; Wiencke, J.K.; Kelsey, K.T. DNA methylation arrays as surrogate measures of cell mixture distribution. BMC Bioinform. 2012, 13, 86. [CrossRef]

44. Ritchie, M.E.; Phipson, B.; Wu, D.; Hu, Y.; Law, C.W.; Shi, W.; Smyth, G.K. Limma powers differential expression analyses for RNA-sequencing and microarray studies. Nucleic Acids Res. 2015, 43, e47. [CrossRef]

45. Graw, S.; Henn, R.; Thompson, J.A.; Koestler, D.C. pwrEWAS: A user-friendly tool for comprehensive power estimation for epigenome wide association studies (EWAS). BMC Bioinform. 2019, 20, 218. [CrossRef]

46. Pacanowski, C.R.; Mason, T.B.; Crosby, R.D.; Mitchell, J.E.; Crow, S.J.; Wonderlich, S.A.; Peterson, C.B. Weight Change over the Course of Binge Eating Disorder Treatment: Relationship to Binge Episodes and Psychological Factors. Obesity 2018, 26, 838-844. [CrossRef]

47. Mirch, M.C.; McDuffie, J.R.; Yanovski, S.Z.; Schollnberger, M.; Tanofsky-Kraff, M.; Theim, K.R.; Krakoff, J.; Yanovski, J.A. Effects of binge eating on satiation, satiety, and energy intake of overweight children. Am. J. Clin. Nutr. 2006, 84, 732-738. [CrossRef]

48. Raymond, N.C.; Neumeyer, B.; Warren, C.S.; Lee, S.S.; Peterson, C.B. Energy intake patterns in obese women with binge eating disorder. Obes. Res. 2003, 11, 869-879. [CrossRef]

49. Raymond, N.C.; Bartholome, L.T.; Lee, S.S.; Peterson, R.E.; Raatz, S.K. A comparison of energy intake and food selection during laboratory binge eating episodes in obese women with and without a binge eating disorder diagnosis. Int. J. Eat. Disord. 2007, 40, 67-71. [CrossRef]

50. Roehrig, M.; Masheb, R.M.; White, M.A.; Grilo, C.M. Dieting frequency in obese patients with binge eating disorder: Behavioral and metabolic correlates. Obesity 2009, 17, 689-697. [CrossRef]

51. Barnes, R.D.; Boeka, A.G.; McKenzie, K.C.; Genao, I.; Garcia, R.L.; Ellman, M.S.; Ellis, P.J.; Masheb, R.M.; Grilo, C.M. Metabolic syndrome in obese patients with binge-eating disorder in primary care clinics: A cross-sectional study. Prim. Care Companion CNS Disord. 2011, 13. [CrossRef]

52. McCuen-Wurst, C.; Ruggieri, M.; Allison, K.C. Disordered eating and obesity: Associations between binge-eating disorder, night-eating syndrome, and weight-related comorbidities. Ann. N. Y. Acad. Sci. 2018, 1411, 96-105. [CrossRef]

53. Wahl, S.; Drong, A.; Lehne, B.; Loh, M.; Scott, W.R.; Kunze, S.; Tsai, P.-C.; Ried, J.S.; Zhang, W.; Yang, Y.; et al. Epigenome-wide association study of body mass index, and the adverse outcomes of adiposity. Nature 2017, 541, 81-86. [CrossRef]

54. Fradin, D.; Boëlle, P.-Y.; Belot, M.-P.; Lachaux, F.; Tost, J.; Besse, C.; Deleuze, J.-F.; De Filippo, G.; Bougnères, P. Genome-Wide Methylation Analysis Identifies Specific Epigenetic Marks in Severely Obese Children. Sci. Rep. 2017, 7, 46311. [CrossRef]

55. Feinberg, A.P.; Irizarry, R.A.; Fradin, D.; Aryee, M.J.; Murakami, P.; Aspelund, T.; Eiriksdottir, G.; Harris, T.B.; Launer, L.; Gudnason, V.; et al. Personalized epigenomic signatures that are stable over time and covary with body mass index. Sci. Transl. Med. 2010, 2, 49ra67. [CrossRef]

56. Xu, Y.; Gray, A.; Hardie, D.G.; Uzun, A.; Shaw, S.; Padbury, J.; Phornphutkul, C.; Tseng, Y.-T. A novel, de novo mutation in the PRKAG2 gene: Infantile-onset phenotype and the signaling pathway involved. Am. J. Physiol. Heart Circ. Physiol. 2017, 313, H283-H292. [CrossRef]

57. Kahn, B.B.; Alquier, T.; Carling, D.; Hardie, D.G. AMP-activated protein kinase: Ancient energy gauge provides clues to modern understanding of metabolism. Cell Metab. 2005, 1, 15-25. [CrossRef] 
58. Steinberg, G.R.; Kemp, B.E. AMPK in Health and Disease. Physiol. Rev. 2009, 89, 1025-1078. [CrossRef]

59. Xiao, B.; Sanders, M.J.; Underwood, E.; Heath, R.; Mayer, F.V.; Carmena, D.; Jing, C.; Walker, P.A.; Eccleston, J.F.; Haire, L.F.; et al. Structure of mammalian AMPK and its regulation by ADP. Nature 2011, 472, 230-233. [CrossRef]

60. Hardie, D.G. AMPK-Sensing energy while talking to other signaling pathways. Cell Metab. 2014, 20, 939-952. [CrossRef]

61. Andersson, U.; Filipsson, K.; Abbott, C.R.; Woods, A.; Smith, K.; Bloom, S.R.; Carling, D.; Small, C.J. AMP-activated protein kinase plays a role in the control of food intake. J. Biol. Chem. 2004, 279, 12005-12008. [CrossRef]

62. Yang, Y.; Atasoy, D.; Su, H.H.; Sternson, S.M. Hunger states switch a flip-flop memory circuit via a synaptic AMPK-dependent positive feedback loop. Cell 2011, 146, 992-1003. [CrossRef] [PubMed]

63. López, M.; Lage, R.; Saha, A.K.; Pérez-Tilve, D.; Vázquez, M.J.; Varela, L.; Sangiao-Alvarellos, S.; Tovar, S.; Raghay, K.; RodríguezCuenca, S.; et al. Hypothalamic fatty acid metabolism mediates the orexigenic action of ghrelin. Cell Metab. 2008, 7, 389-399. [CrossRef] [PubMed]

64. Minokoshi, Y.; Alquier, T.; Furukawa, N.; Kim, Y.-B.; Lee, A.; Xue, B.; Mu, J.; Foufelle, F.; Ferré, P.; Birnbaum, M.J.; et al. AMP-kinase regulates food intake by responding to hormonal and nutrient signals in the hypothalamus. Nature 2004, 428, 569-574. [CrossRef] [PubMed]

65. Stark, R.; Ashley, S.E.; Andrews, Z.B. AMPK and the neuroendocrine regulation of appetite and energy expenditure. Mol. Cell. Endocrinol. 2013, 366, 215-223. [CrossRef] [PubMed]

66. Yavari, A.; Stocker, C.J.; Ghaffari, S.; Wargent, E.T.; Steeples, V.; Czibik, G.; Pinter, K.; Bellahcene, M.; Woods, A.; Martínez de Morentin, P.B.; et al. Chronic Activation of $\gamma 2$ AMPK Induces Obesity and Reduces $\beta$ Cell Function. Cell Metab. 2016, 23, 821-836. [CrossRef] [PubMed]

67. Claret, M.; Smith, M.A.; Batterham, R.L.; Selman, C.; Choudhury, A.I.; Fryer, L.G.D.; Clements, M.; Al-Qassab, H.; Heffron, H.; $\mathrm{Xu}, \mathrm{A} . \mathrm{W}$; et al. AMPK is essential for energy homeostasis regulation and glucose sensing by POMC and AgRP neurons. J. Clin. Investig. 2007, 117, 2325-2336. [CrossRef]

68. Rojas, J.; Arraiz, N.; Aguirre, M.; Velasco, M.; Bermúdez, V. AMPK as Target for Intervention in Childhood and Adolescent Obesity. J. Obes. 2011, 2011, 252817. [CrossRef]

69. Ha, E.; Yim, S.V.; Jung, K.H.; Yoon, S.H.; Zheng, L.T.; Kim, M.J.; Hong, S.J.; Choe, B.K.; Baik, H.H.; Chung, J.H.; et al. Topiramate stimulates glucose transport through AMP-activated protein kinase-mediated pathway in L6 skeletal muscle cells. Pharm. J. 2006, 6, 327-332. [CrossRef]

70. Cool, B.; Zinker, B.; Chiou, W.; Kifle, L.; Cao, N.; Perham, M.; Dickinson, R.; Adler, A.; Gagne, G.; Iyengar, R.; et al. Identification and characterization of a small molecule AMPK activator that treats key components of type 2 diabetes and the metabolic syndrome. Cell Metab. 2006, 3, 403-416. [CrossRef]

71. Zhang, B.B.; Zhou, G.; Li, C. AMPK: An emerging drug target for diabetes and the metabolic syndrome. Cell Metab. 2009, 9, 407-416. [CrossRef] [PubMed]

72. Fujita, A.; Okuno, T.; Oda, M.; Kato, K. Urinary volatilome analysis in a mouse model of anxiety and depression. PLoS ONE 2020, 15, e0229269. [CrossRef]

73. Srimontri, P.; Endo, S.; Sakamoto, T.; Nakayama, Y.; Kurosaka, A.; Itohara, S.; Hirabayashi, Y.; Kato, K. Sialyltransferase ST3Gal IV deletion protects against temporal lobe epilepsy. J. Neurochem. 2014, 131, 675-687. [CrossRef]

74. Sugie, K.; Kawakami, T.; Maeda, Y.; Kawabe, T.; Uchida, A.; Yodoi, J. Fyn tyrosine kinase associated with Fc epsilon RII/CD23: Possible multiple roles in lymphocyte activation. Proc. Natl. Acad. Sci. USA 1991, 88, 9132-9135. [CrossRef]

75. Calautti, E.; Grossi, M.; Mammucari, C.; Aoyama, Y.; Pirro, M.; Ono, Y.; Li, J.; Dotto, G.P. Fyn tyrosine kinase is a downstream mediator of Rho/PRK2 function in keratinocyte cell-cell adhesion. J. Cell Biol. 2002, 156, 137-148. [CrossRef] [PubMed]

76. Mkaddem, S.B.; Murua, A.; Flament, H.; Titeca-Beauport, D.; Bounaix, C.; Danelli, L.; Launay, P.; Benhamou, M.; Blank, U.; Daugas, E.; et al. Lyn and Fyn function as molecular switches that control immunoreceptors to direct homeostasis or inflammation. Nat. Commun. 2017, 8, 246. [CrossRef]

77. Shang, G.; Tang, X.; Gao, P.; Guo, F.; Liu, H.; Zhao, Z.; Chen, Q.; Jiang, T.; Zhang, N.; Li, H. Sulforaphane attenuation of experimental diabetic nephropathy involves GSK-3 beta/Fyn/Nrf2 signaling pathway. J. Nutr. Biochem. 2015, $26,596-606$. [CrossRef]

78. Lim, J.C.; Kim, G.; Levine, R.L. Stereospecific oxidation of calmodulin by methionine sulfoxide reductase A. Free Radic. Biol. Med. 2013, 61, 257-264. [CrossRef]

79. Annerén, C. Dual role of the tyrosine kinase GTK and the adaptor protein SHB in beta-cell growth: Enhanced beta-cell replication after $60 \%$ pancreatectomy and increased sensitivity to streptozotocin. J. Endocrinol. 2002, 172, 145-153. [CrossRef] [PubMed]

80. Annerén, C.; Welsh, M. Increased cytokine-induced cytotoxicity of pancreatic islet cells from transgenic mice expressing the Src-like tyrosine kinase GTK. Mol. Med. 2001, 7, 301-310. [CrossRef]

81. Boyd, H.K.; Bodell, L.P.; Jennings, K.M.; Graham, A.K.; Crosby, R.D.; Wildes, J.E. Relationship between desired weight constructs and eating disorder severity following treatment for anorexia nervosa. Int. J. Eat. Disord. 2018, 51, 870-878. [CrossRef] 